\title{
Evaluation of seed morphology characteristics of Alnus taxa in Iran
}

\author{
T. Gholami-Terojeni ${ }^{1,5}$, F. Sharifnia ${ }^{2,6 *}$, T. Nejadsattari ${ }^{1,7}$, M. Assadi ${ }^{3,8}$, S. M. M. Hamdi ${ }^{4,9}$ \\ ${ }^{1}$ Department of Biology, Science and Research Branch, Islamic Azad University, Tehran, Iran \\ ${ }^{2}$ Department of Biology, North Tehran Branch, Islamic Azad University, Tehran, Iran \\ ${ }^{3}$ Research Institute of Forests and Rangelands, Agricultural Research Education \\ and Extension Organization (AREEO), Tehran, Iran \\ ${ }^{4}$ Department of Biology, Central Tehran Branch, Islamic Azad University, Tehran, Iran \\ ${ }^{5}$ ORCID iD: https://orcid.org/0000-0003-4139-2146 \\ ${ }^{6}$ E-mail: faribasharifnia2234@gmail.com; ORCID iD: https://orcid.org/0000-0002-8984-3316 \\ ${ }^{7}$ ORCID iD: https://orcid.org/0000-0003-0822-2284 \\ ${ }^{8}$ ORCID iD: https://orcid.org/0000-0001-9014-585X \\ ${ }^{9}$ ORCID iD: https://orcid.org/0000-0001-7167-1352 \\ * Corresponding author
}

Keywords: Betulaceae, Hyrcanian forests, infraspecific variation, micromorphology, taxonomy.

Summary. Alnus Mill. is a problematic genus of Betulaceae, and there are several intrageneric classifications for the genus. Alnus species are widely distributed in the Hyrcanian forest of Iran, and different species with some intraspecific taxonomic ranks including subspecies and varieties have been reported from this country. We evaluate seed micromorphology characteristics of ten taxa using scanning electron microscopy and light microscopy in the current study. The data were analyzed using SPSS and MVSP software. Results revealed that qualitative characteristics such as seed shape, surface sculpturing pattern, presence of indumentum, and its type vary among the studied taxa and have diagnostic value. However, seed color was nearly stable among the taxa. Besides, quantitative variables highly differed among the taxa. In the UPGMA tree, Alnus taxa were clustered into three groups, and these groups were supported by PCA and PCO plots. According to the PCA bi-plot, some taxa were characterized by the particular characteristic(s) that was useful for their identification. In some cases taxa clustering was similar to those of previous phylogenetic and morphological studies. Our findings revealed that seed morphology characteristics are a valuable taxonomical tool in identifying most Alnus taxa, except for A. glutinosa subspecies, which have similar seed morphology features in common.

\section{Оценка морфологических признаков семян иранских представителей рода Alnus}

\author{
Т. Гхолами-Тероджени ${ }^{1}$, Ф. Шарифниа ${ }^{2}$ Т. Неджадсаттари ${ }^{1}$, М. Ассади ${ }^{3}$, С. М. М. Хамди ${ }^{4}$ \\ ${ }^{1}$ Биологический факультет, Научно-исследовательский филиал Исламского Университета Азад, г. Тегеран, Иран \\ ${ }^{2}$ Биологический факультет, Тегеранский Северный филиал Исламского Университета Азад, г. Тегеран, Иран \\ ${ }^{3}$ Научно-исследовательский институт лесов и пастбищ, Организация сельскохозяйственных исследований, \\ образования и распространения знаний (AREEO), г. Тегеран, Иран
}

${ }^{4}$ Биологический факультет, Тегеранский Центральный филиал Исламского Университета Азад, г. Тегеран, Иран 
Ключевые слова: гирканские леса, инфраспецифическая изменчивость, микроморфология, таксономия, Betulaceae.

\begin{abstract}
Аннотация. Род Alnus Mill. (Betulaceae) - ольха - является таксономически сложным, и в настоящее время для него предложено несколько классификаций. Исследования иранских видов ольхи, встречающихся в гирканских лесах, доказали наличие на этой территории различных внутривидовых таксономических единиц, включая подвиды и разновидности. В настоящем исследовании мы оцениваем микроморфологические характеристики семян десяти таксонов, используя методы сканирующей электронной и световой микроскопии. Данные были проанализированы с использованием программного обеспечения SPSS и MVSP. Результаты показали, что такие качественные характеристики, как форма семян, структура поверхности, наличие волосков и их тип, но не цвет семян, различаются у исследованных таксонов и имеют диагностическое значение; количественные показатели также показали существенные различия. На графиках UPGMA, построенных при помощи метода невзвешенного попарного среднего, таксоны Alnus сгруппировались в три кластера, которые соответствовали группам, полученным при помощи методов главных компонент (РСА) и главных координат (PCO). Согласно двумерным графикам РСА, определённые признаки некоторых таксонов имеют таксономическую значимость. В ряде случаев результаты кластерного анализа оказались схожи с таковыми предыдущих филогенетических и морфологических исследований. Наши результаты показали, что, за исключением подвидов A. glutinosa, морфологические характеристики семян являются ценным таксономическим инструментом идентификации изученных таксонов Alnus.
\end{abstract}

\section{Introduction}

Alnus Mill. is a genus of Betulaceae which grows around the Northern Hemisphere and in the Andes mountains of the Southern Hemisphere. There are 29-35 species of the genus in the world, that about 18-23 species are found naturally in Asia, 9 of them in the New World and 4-5 species in Europe (Ashburner, 1986; Chen, 1994; Govaerts, Frodin, 1998).

According to some evaluations (Miki, 1997), fossil pollen grains of Alnus species have been reported from the late Cretaceous of western North America and Japan. However, no megafossils prior to the Tertiary have been reliably assigned to the genus.

In the Hyrcanian forests, the trees of this genus have many critical roles especially in forest rehabilitation. Like most of woody plants in Hyrcanian forests, there are many taxonomic problems concerning the recognition of Alnus species in Iran. During the long-term investigation in the most parts of Hyrcanian forests, several samples of Alnus taxa were collected from different locations. According to the previous investigations (Browicz, 1972; Mobayen, 1985), the genus in Iran comprises of two species: Alnus glutinosa (L.) Gaertn. subsp. barbata (C. A. Mey.) Yalt. and A. subcordata C. A. Mey. with two varieties that are found in these forests. While, results of more recent studies showed that there are some new species and subspecies in Iran, including: A. djavanshirii $\mathrm{H}$. Zare, A. dolichocarpa H. Zare, Amini et Assadi and A. orientalis Decne., A. glutinosa subsp. glutinosa and A. glutinosa subsp. antitaurica Yalt. (Zare, Amini, 2012).

According to morphological characters, geographic distribution and phylogenetic analyses some subgenera and sections were definite for the genus (Chen, Li, 2004).

In this regard, Alnus phylogenetic analyses revealed that this genus is a monophyletic group (Murai, 1964; Navarro et al., 2003; Gholamiterojeni et al., 2019). Chen and Li (2004) applied sequences of nuclear ribosomal DNA (ITS region) to detect phylogenetic relationships of the genus and recognized three major clades including subgenera Alnus, Alnobetula (Ehrhart.) Peterman and Clethropsis (Spach.) Murai. Moreover, the analysis revealed that subgenus Alnobetula is sister to other subgenera.

Kaya et al. (2011) believed that seed morphology characters are an important trait in taxonomical treatment of various families. These characteristics are mostly used to resolve taxonomical problems concerning closely related species, taxa delimitation and establish their evolutionary relationships (Sukhorukov et al., 2018).

There are several taxonomical treatments of the genus in Iran. For example, Shayanmehr et al. (2014) evaluated morphological characteristics of different Alnus taxa in Iran. The molecular phylogeny of the genus according to two DNA barcode markers was not congruent with the last morphological classifications (Hosseinzadeh-Colagar et al., 2016), and Gholamiterojeni et al. (2019) performed a revision of this genus in the country using molecular ITS markers and morphological characters and 
recognized some new taxa. But we could not find any study related to seed micromorphology of Alnus in Iran.

In the current study, we evaluate seed morphology characteristics of 10 Iranian Alnus taxa. The main aims for this study were: (1) to study and compare the seed morphological and micromorphological characteristics of the taxa for the first time; (2) study the seed traits have taxonomic importance, and whether are useful in identification of the investigated taxa, and (3) study the classification of taxa based on seed characters and compare with the previous taxonomical treatments of the genus.

\section{Material and methods}

\section{Plant samples}

Plant samples of ten Alnus taxa were collected from the northern slops of Albourz Mountains of Hyrcanian forests from the north of Iran (Table 1). Three trees were studied for each taxon. Plant samples of taxa were identified based on the descriptions provided in different flora such as "Flora Orientalis" (Boissier, 1867), "Flora of USSR" (Kuzeneva, 1936), "Flora Iranica" (Browicz, 1972), "Flora of Turkey" (Yaltrik, 1982), and "Flora of Iran" (Zare, Aimini, 2012). Herbarium vouchers are housed in the herbarium of Tehran North Branch, Islamic Azad University (IAUNT).

Six seed samples were investigated for each taxon. Different quantitative and qualitative seed morphology characters such as color, shape, length, width and length/width ratio, hilum and wings length were evaluated using Olympus $\mathrm{CH}_{2}$ light microscope. Six repetition were made for each studied traits.

For Scanning Electron Microscopy (SEM) examination, the mature and intact seeds were directly transferred to a stub with double-sided tape. Seeds were gold-coated in a JFC-1600 Auto Fine Coater and observed under a SU 3500 scanning electron microscope. Some characteristics such as indumentum and surface sculpturing types were evaluated in SEM micrographs.

Table 1

Localities addresses and herbarium voucher number of the studied Alnus species

\begin{tabular}{|l|l|c|c|c|}
\hline \multicolumn{1}{|c|}{ Taxon } & \multicolumn{1}{|c|}{ Locality } & $\begin{array}{c}\text { Elevation } \\
(\mathrm{m})\end{array}$ & \multicolumn{1}{c|}{$\begin{array}{c}\text { Geographic } \\
\text { coordinates }\end{array}$} & Voucher no. \\
\hline A. hyrcana & Golestan, National park & 471 & $37^{\circ} 23^{\prime} \mathrm{N}, 55^{\circ} 48^{\prime} \mathrm{E}$ & IAUNT 16720 \\
\hline A. subcordata var. subcordata & Golestan, Gorgan & 477 & $36^{\circ} 46^{\prime} \mathrm{N}, 54^{\circ} 28^{\prime} \mathrm{E}$ & IAUNT 16727 \\
\hline A. subcordata var. villosa & Mazandaran, Gelvard & 753 & $36^{\circ} 35^{\prime} \mathrm{N}, 53^{\circ} 36^{\prime} \mathrm{E}$ & IAUNT 16732 \\
\hline A. longiflorescentia & Golestan, Gorgan & 640 & $36^{\circ} 07^{\prime} \mathrm{N}, 53^{\circ} 03^{\prime} \mathrm{E}$ & IAUNT 16719 \\
\hline A. djavanshirii & Mazandaran, Behshahr & 443 & $36^{\circ} 39^{\prime} \mathrm{N}, 53^{\circ} 30^{\prime} \mathrm{E}$ & IAUNT 16729 \\
\hline A. orientalis & Mazandaran, Neka & 478 & $36^{\circ} 34^{\prime} \mathrm{N}, 53^{\circ} 29^{\prime} \mathrm{E}$ & IAUNT 16731 \\
\hline A. glutinosa subsp. glutinosa & Mazandaran, Chaboksar & -45 & $37^{\circ} 03^{\prime} \mathrm{N}, 50^{\circ} 25^{\prime} \mathrm{E}$ & IAUNT 16743 \\
\hline A. glutinosa subsp. antitaurica & $\begin{array}{l}\text { Mazandaran, Mahmood } \\
\text { Abad }\end{array}$ & -20 & $36^{\circ} 36^{\prime} \mathrm{N}, 52^{\circ} 12^{\prime} \mathrm{E}$ & IAUNT 16734 \\
\hline A. glutinosa subsp. barbata & Guilan, Talesh & -13 & $37^{\circ} 41^{\prime} \mathrm{N}, 48^{\circ} 59^{\prime} \mathrm{E}$ & IAUNT 16751 \\
\hline A. dolichocarpa & Guilan, Astara & -10 & $38^{\circ} 12^{\prime} \mathrm{N}, 48^{\circ} 53^{\prime} \mathrm{E}$ & IAUNT 16749 \\
\hline
\end{tabular}

\section{Statistical analyses}

The mean and standard deviation of each examined quantitative characteristics were calculated by SPSS ver. 15. In order to do cluster analysis, data were standardized, mean of 0 and standard deviation of 1 . These analyses were carried out with qualitative and quantitative characteristics using Unweighted Paired Group Method with Arithmetic Mean (UPGMA), Principal Coordinate Ordination (PCO), Principal Component Analysis (PCA) and PCA bi-plots clustering in Multivariate Statistical Package (MVSP) program (Podani, 2000).

\section{Results}

Seed morphology characteristics are presented in Table 2. Seed quantitative characters differ among the studied taxa. Longest and shortest seeds are observed in A. dolichocarpa and A. glutinosa subsp. glutinosa, respectively. In addition, the broadest and narrowest seeds are reported from $A$. orientalis and A. glutinosa subsp. antitaurica, respectively. All studied taxa have wings, except for A. djavanshirii. In this regard, the largest wings are registered in A. orientalis, and the shortest ones are in A. subcordata var. villosa and A. glutinosa subsp. 
antitaurica. The longest and shortest hilum are found in A. hyrcana and A. longiflorescentia, respectively.

Furthermore, the qualitative characters vary among the taxa. The seed shape is: elliptic (A. glutinosa subsp. glutinosa, A. glutinosa subsp. antitaurica, A. glutinosa subsp. barbata, A. orientalis, and A. dolichocarpa), cordate (A. subcordata var. subcordata), elongate (A. subcordata var. villosa), five-angled (A. djavanshirii, A. hyr- cana and A. longiflorescentia). Surface sculpture differs as foveolate (A. glutinosa subsp. glutinosa, A. glutinosa subsp. antitaurica, A. glutinosa subsp. barbata), rugose (A. djavanshirii, A. hyrcana and A. orientalis), papilla (A. longiflorescentia), reticulate striate (A. subcordata var. subcordata) and reticulate tabular (A. subcordata var. villosa) (Figs. 1, 2).

Table 2

Seed morphological and micromorphological characteristics of the studied taxa (all values in $\mathrm{mm}$ )

\begin{tabular}{|c|c|c|c|c|c|c|c|c|c|}
\hline Taxa & Length & Width & $\begin{array}{l}\text { Length/ } \\
\text { width } \\
\text { ratio }\end{array}$ & Color & Shape & $\begin{array}{l}\text { Epidermis } \\
\text { cell pattern }\end{array}$ & Indumentum & Wing & Hilum \\
\hline $\begin{array}{l}\text { A. glutinosa } \\
\text { subsp. } \\
\text { glutinosa }\end{array}$ & $\begin{array}{c}2.64 \pm \\
0.77\end{array}$ & $\begin{array}{c}2.56 \pm \\
0.56\end{array}$ & $\begin{array}{c}0.96 \pm \\
0.11\end{array}$ & $\begin{array}{l}\text { Dark } \\
\text { Green }\end{array}$ & Elliptic & Foveolate & Pilose & $\begin{array}{c}0.6 \pm \\
0.08\end{array}$ & $\begin{array}{c}0.8 \pm \\
0.1\end{array}$ \\
\hline $\begin{array}{l}\text { A. glutinosa } \\
\text { subsp. } \\
\text { antitaurica }\end{array}$ & $\begin{array}{c}3.06 \pm \\
0.19\end{array}$ & $\begin{array}{c}2.49 \pm \\
0.29\end{array}$ & $\begin{array}{c}1.22 \pm \\
0.78\end{array}$ & $\begin{array}{l}\text { Dark } \\
\text { Green }\end{array}$ & Elliptic & Foveolate & Pilose & $\begin{array}{l}0.1 \pm \\
0.04\end{array}$ & $\begin{array}{l}0.7 \pm \\
0.05\end{array}$ \\
\hline $\begin{array}{l}\text { A. glutinosa } \\
\text { subsp. barbata }\end{array}$ & $\begin{array}{c}3.62 \pm \\
0.66 \\
\end{array}$ & $\begin{array}{c}2.86 \pm \\
.71 \\
\end{array}$ & $\begin{array}{l}1.26 \pm \\
0.57 \\
\end{array}$ & $\begin{array}{c}\text { Dark } \\
\text { Green } \\
\end{array}$ & Elliptic & Foveolate & Pilose & $\begin{array}{c}0.7 \pm \\
0.1 \\
\end{array}$ & $\begin{array}{c}0.8 \pm \\
0.07 \\
\end{array}$ \\
\hline $\begin{array}{l}\text { A. subcordata } \\
\text { var. } \\
\text { subcordata }\end{array}$ & $\begin{array}{c}3.83 \pm \\
0.38\end{array}$ & $\begin{array}{c}3.2 \pm \\
1.1\end{array}$ & $\begin{array}{c}1.19 \pm \\
0.43\end{array}$ & $\begin{array}{l}\text { Dark } \\
\text { Green }\end{array}$ & Cordate & $\begin{array}{c}\text { Reticulate- } \\
\text { Striate }\end{array}$ & - & $\begin{array}{c}0.6 \pm \\
0.11\end{array}$ & $\begin{array}{l}0.8 \pm \\
0.13\end{array}$ \\
\hline $\begin{array}{l}\text { A. subcordata } \\
\text { var. villosa }\end{array}$ & $\begin{array}{c}4.07 \pm \\
0.18 \\
\end{array}$ & $\begin{array}{c}2.69 \pm \\
0.47 \\
\end{array}$ & $\begin{array}{c}1.51 \pm \\
0.7 \\
\end{array}$ & $\begin{array}{c}\text { Dark } \\
\text { Green }\end{array}$ & Elongate & $\begin{array}{c}\text { Reticulate- } \\
\text { Tubular }\end{array}$ & tomentose & $\begin{array}{l}0.1 \pm \\
0.05\end{array}$ & $\begin{array}{c}0.5 \pm \\
0.12 \\
\end{array}$ \\
\hline A. djavanshirii & $\begin{array}{c}4.23 \pm \\
0.39\end{array}$ & $\begin{array}{c}2.92 \pm \\
0.59 \\
\end{array}$ & $\begin{array}{l}1.44 \pm \\
0.85\end{array}$ & $\begin{array}{l}\text { Light } \\
\text { Green }\end{array}$ & $\begin{array}{c}\text { Five- } \\
\text { Angled }\end{array}$ & Regose & - & 0 & $\begin{array}{c}0.6 \pm \\
0.09\end{array}$ \\
\hline A. orientalis & $\begin{array}{c}3.55 \pm \\
0.17\end{array}$ & $\begin{array}{c}3.37 \pm \\
0.32 \\
\end{array}$ & $\begin{array}{l}1.05 \pm \\
0.56\end{array}$ & $\begin{array}{l}\text { Light } \\
\text { Green }\end{array}$ & Elliptic & Regose & - & $\begin{array}{c}0.9 \pm \\
0.08\end{array}$ & $\begin{array}{c}0.9 \pm \\
0.1\end{array}$ \\
\hline $\begin{array}{l}\text { A. dolicho- } \\
\text { carpa }\end{array}$ & $\begin{array}{c}4.32 \pm \\
0.78\end{array}$ & $\begin{array}{c}3.31 \pm \\
0.41 \\
\end{array}$ & $\begin{array}{l}1.03 \pm \\
0.28\end{array}$ & $\begin{array}{l}\text { Light } \\
\text { Green }\end{array}$ & Elliptic & Reticulate & - & $\begin{array}{c}0.8 \pm \\
0.07\end{array}$ & $\begin{array}{c}1 \pm \\
0.11\end{array}$ \\
\hline A. hyrcana & $\begin{array}{c}3.92 \pm \\
0.44\end{array}$ & $\begin{array}{c}3.35 \pm \\
0.61\end{array}$ & $\begin{array}{c}1.17 \pm \\
0.4\end{array}$ & $\begin{array}{c}\text { Dark } \\
\text { Green }\end{array}$ & $\begin{array}{c}\text { Five- } \\
\text { Angled }\end{array}$ & Regose & - & $\begin{array}{c}0.7 \pm \\
0.06\end{array}$ & $\begin{array}{c}1.08 \pm \\
0.22\end{array}$ \\
\hline $\begin{array}{l}\text { A. longiflo- } \\
\text { rescentia }\end{array}$ & $\begin{array}{c}2.9 \pm \\
0.35\end{array}$ & $\begin{array}{c}2.89 \pm \\
0.74\end{array}$ & $\begin{array}{c}0.99 \pm \\
0.83\end{array}$ & $\begin{array}{l}\text { Light } \\
\text { Green }\end{array}$ & $\begin{array}{c}\text { Five- } \\
\text { Angled }\end{array}$ & Papilla & - & $\begin{array}{c}0.5 \pm \\
0.01\end{array}$ & $\begin{array}{c}0.3 \pm \\
0.1\end{array}$ \\
\hline
\end{tabular}

The seed surface of some taxa is covered by indumentum. It is pilose (A. glutinosa subsp. antitaurica, A. glutinosa subsp. glutinosa and A. glutinosa subsp. barbata) or tomentose (A. subcordata var. villosa).

According to UPGMA tree of seed morphology characteristics, the studied taxa are divided into three distinct groups: all studied subspecies of A. glutinosa with $A$. subcordata var. villosa constituent the first group. The second group is composed of $A$. dolichocarpa, A. orientalis and A. subcordata var. subcordata. The rest species, A. longiflorescentia, A. hyrcana and A. djavanshirii are clustered as the third group (Fig. 3). Furthermore, the PCA and PCO plots produce the similar outputs (Figs. 4, 5).
PCA bi-plot revealed that taxa were characterized by the special characteristic(s) that is useful in identification of them. For example, indumentum type and seed shape were the diagnostic features for A. subcordata var. villosa and A. subcordata var. subcordata, respectively. Besides, A. hyrcana was characterized by hilum length and $A$. dolichocarpa and $A$. oreintalis by wing length (Fig. 6).

\section{Discussion}

In this research, we used seed morphology characteristics of ten Iranian Alnus taxa for evaluating their taxonomical importance and taxa delimitation. Previous evaluations (Talebi et al., 2012, 2019) revealed that seed morphology 
characteristics play a prominent role in infrageneric classification and also identification of different taxa.

We tested both qualitative and quantitative seed morphological variables. Among qualitative features, seed color was stable at intraspecific level, either subspecies or variety. However, in some cases, it had a diagnostic value at the specific level. Against, seed shape and epidermis cell sculpturing pattern were more variable traits than the seed color. We found four types of seed shape and six types of seed surface sculpturing pattern. Both characteristics were stable at intraspecific level, while they had the diagnostic value at the variety level. Meanwhile, in several cases, these features were useful in Alnus species identification. Koul et al. (2000) suggested that seed surface patterns reflect adaption and natural selection. Furthermore, this feature has taxonomic significance at the generic and specific levels (Brochmann, 1992).

We found two types of indumentum on the seed surface of Alnus taxa. It is more important to know that indumentum was only observed in three subspecies of $A$. glutinosa (in the same shape) and A. subcordata var. villosa. Using this feature, we could distinguish two varieties of $A$. subcordata. Therefore, the existence and type of indumentum were the valuable traits for identification of Alnus taxa. The results of Shayanmehr et al. (2018) investigation revealed the suitability of ultrastructure characteristics such as a micro-morphological structure for solving the taxonomical ambiguities in this genus. In more recent morphological characteristics, both varieties of $A$. subcordata placed far from each other in different groups (Gholamiterojeni et al., 2019).

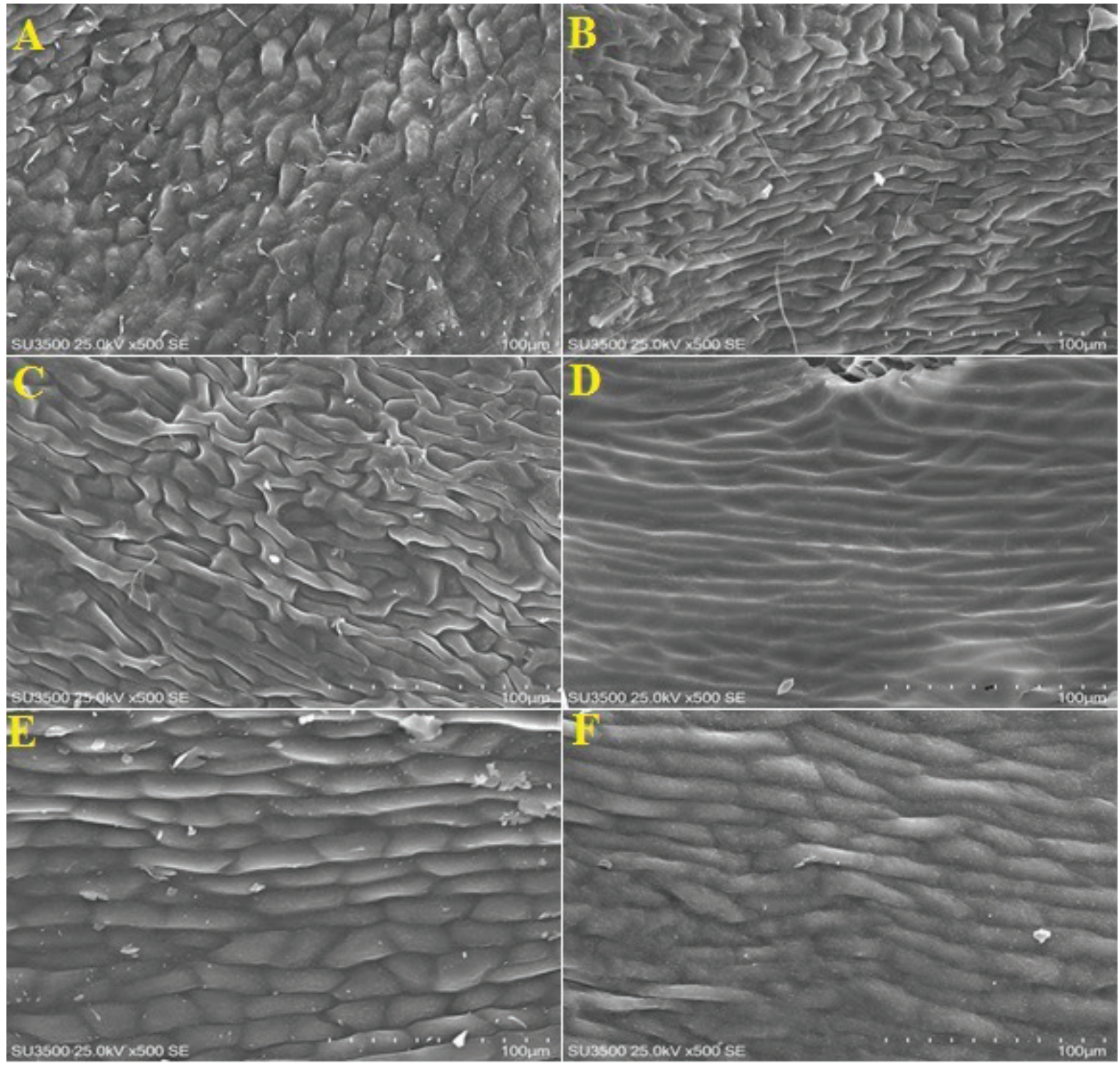

Fig. 1. SEM micrograph of seed surfaces of the studied taxa. A - Alnus glutinosa subsp. glutinosa; B - A. glutinosa subsp. antitaurica; $\mathrm{C}-A$. glutinosa subsp. barbata; D, E - A. subcordata var. subcordata; F - A. dolichocarpa. 


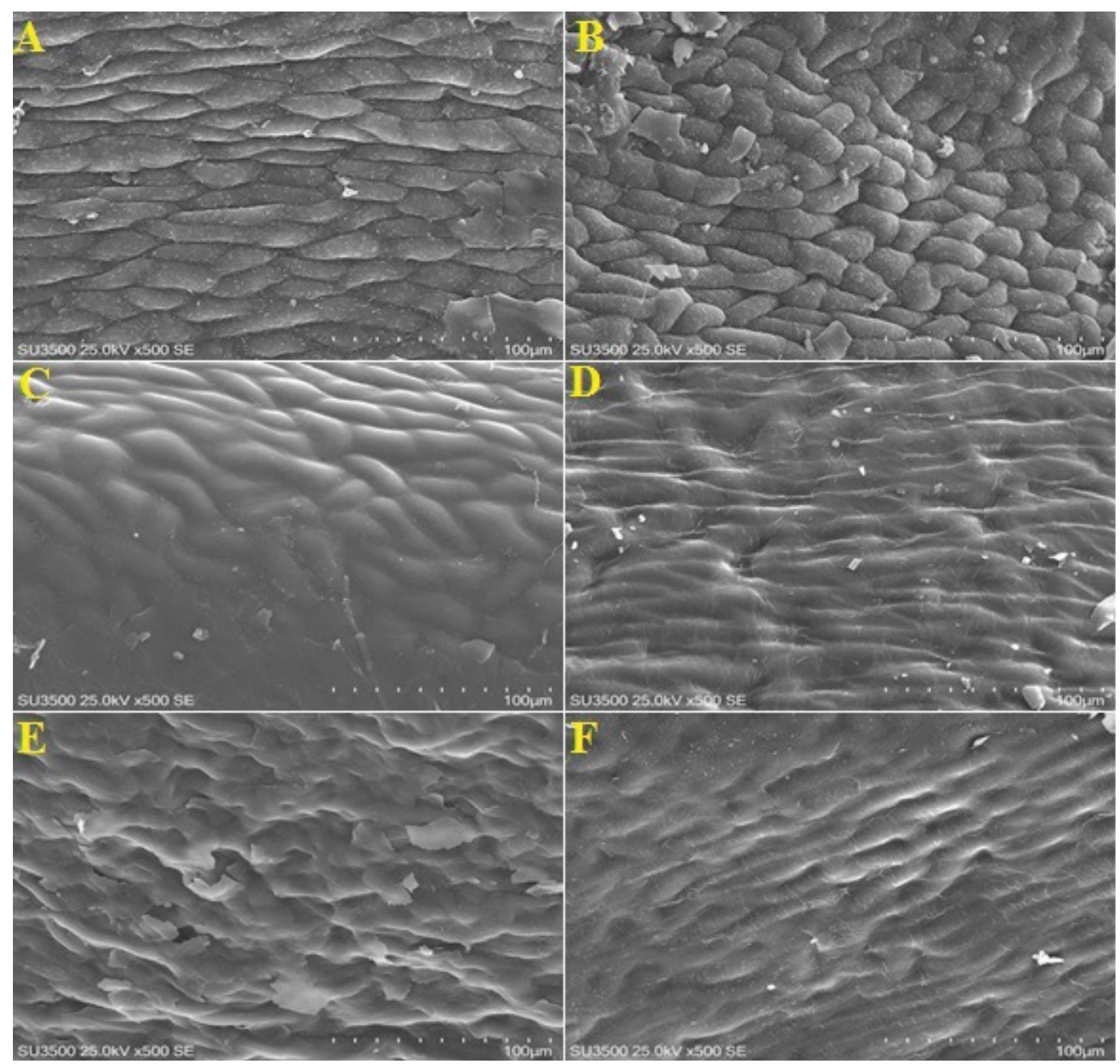

Fig. 2. SEM micrograph of the seed surfaces of the studied taxa. A, B - A. subcordata var. villosa; C - A. djavanshirii; $\mathrm{D}-$ A. orientalis; $\mathrm{E}-$ A. longiflorescentia $; \mathrm{F}-$ A. hyrcana.

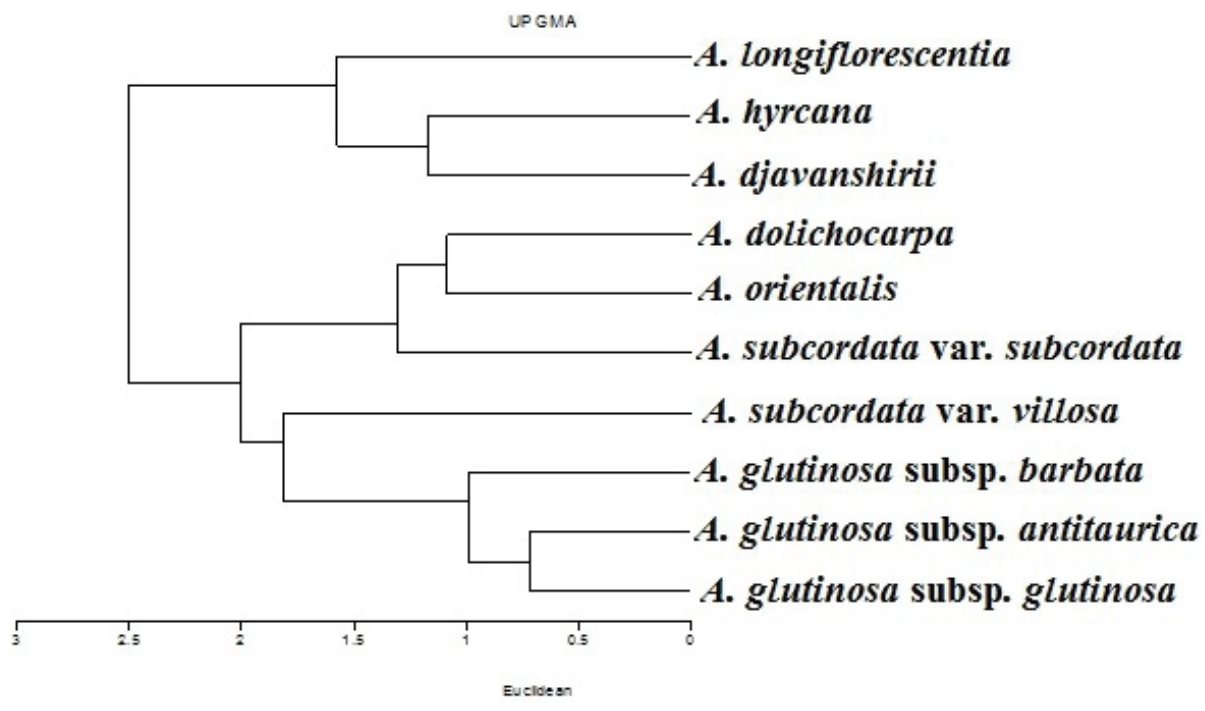

Fig. 3. UPGMA tree of the studied Alnus taxa, according to seed morphological features. 


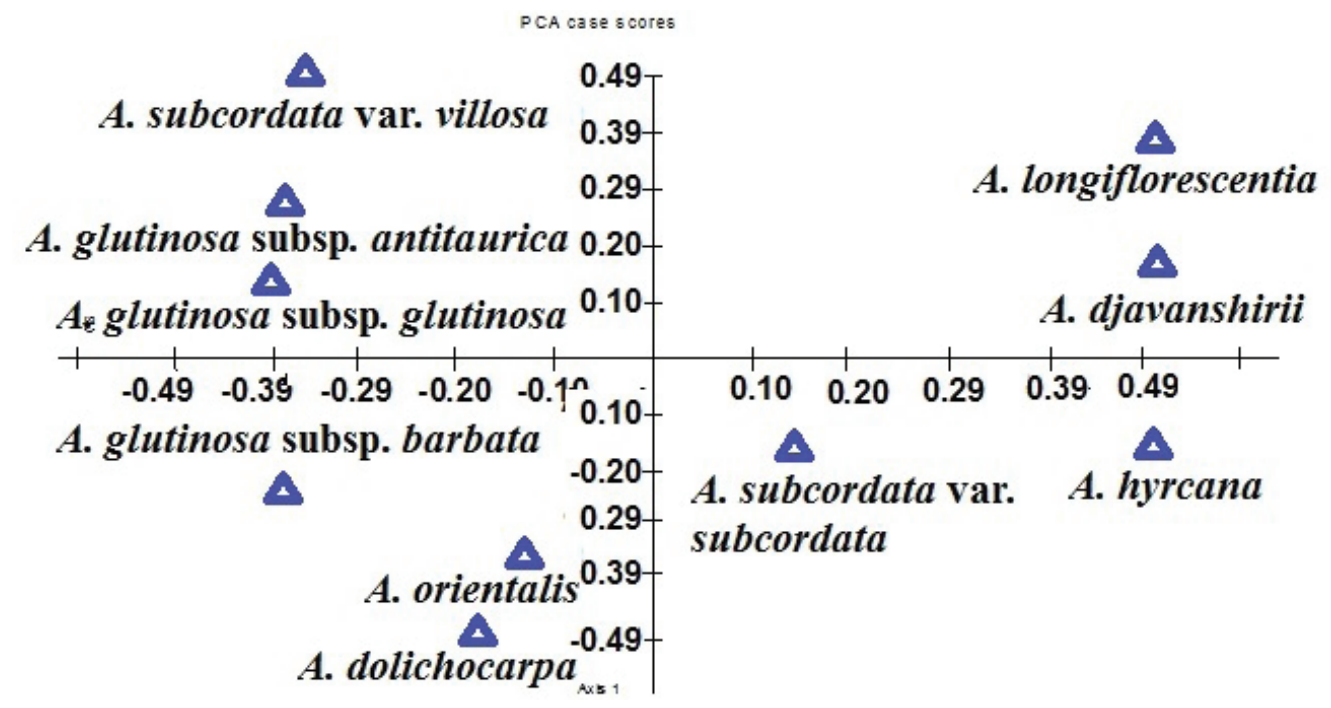

Fig. 4. PCA plot of the studied Alnus taxa based on the seed characteristics.

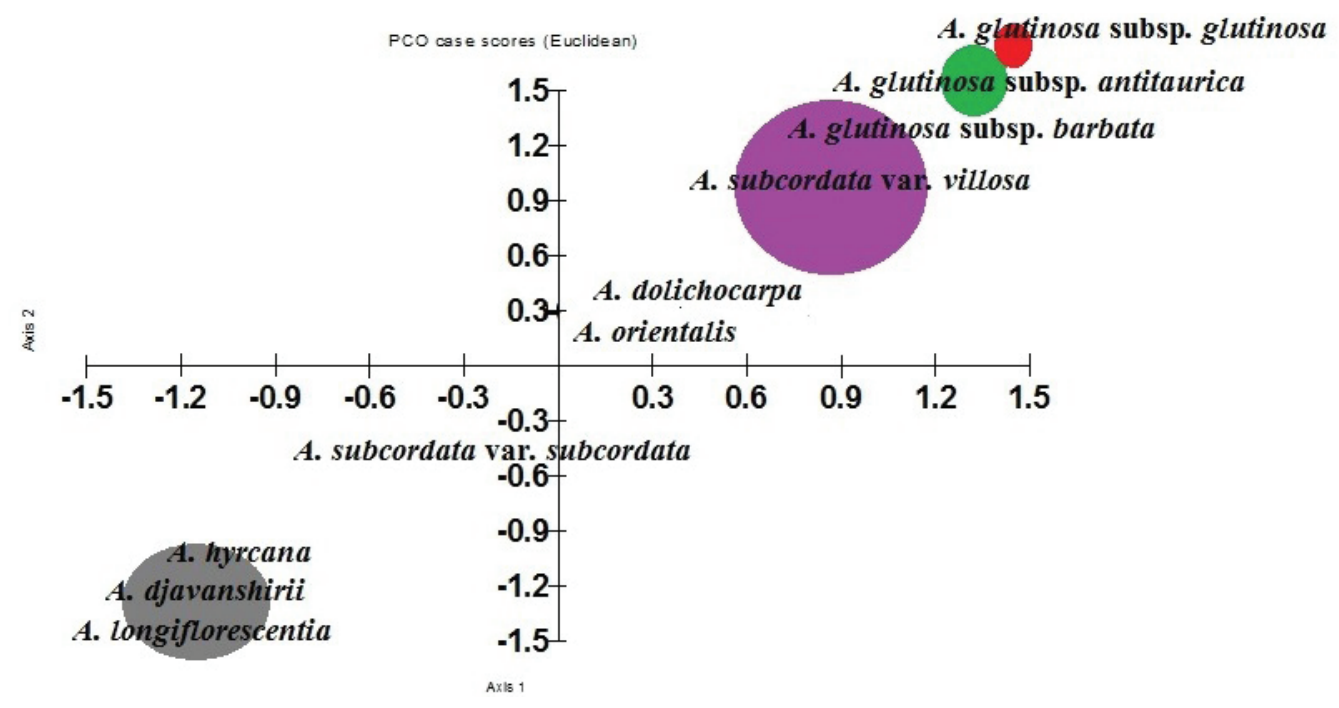

Fig. 5. PCO plot of the evaluated taxa according to the investigated features of Alnus taxa seeds.

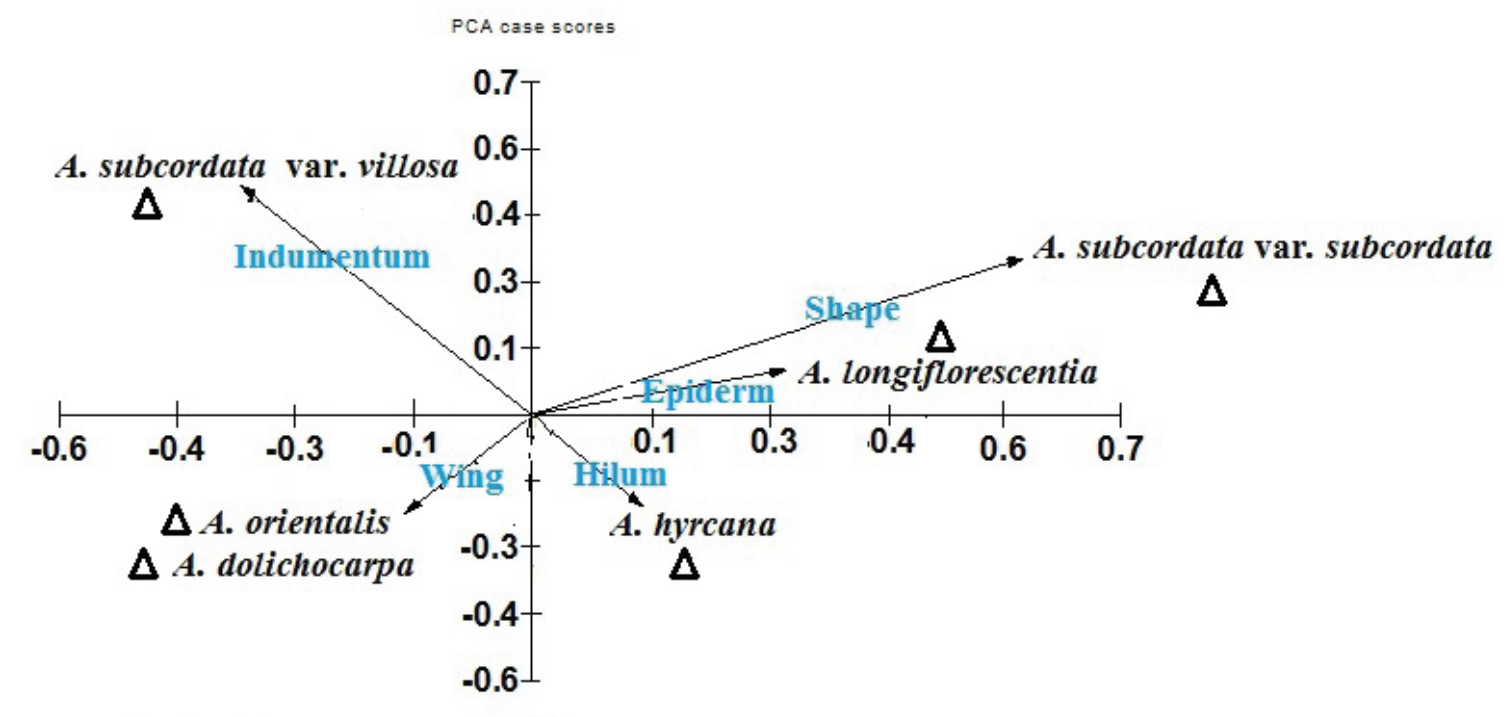

Vector scalina: 0.77

Fig. 6. PCA Bi-plot of the studied Alnus taxa and their seed features. 
Quantitative seed morphological characteristics varied among the taxa and could be used as the diagnostic features in taxa identification, as shown by PCA bi-plot. According to seed morphological UPGMA tree, three subspecies of $A$. glutinosa were close together. Similar results were reported by Shayanmehr et al. (2014) and Gholamiterojeni et al. (2019). They investigated morphological features and phylogenetic relationship using molecular ITS markers of some Alnus taxa and reported that these sub-species had very similar features. Meanwhile, Hosseinzadeh-Colagar et al. (2016) analyzed of trnH-psbA sequence data of different Alnus taxa and suggested that the recognized A. glutinosa subspecies were distributed among the other species of the genus.

According to previous morphological study, $A$. dolichocarpa and A. djavanshirii were very similar to that of $A$. subcordata var. subcordata (Shayanmehr et al., 2014). In our study, A. subcordata var. subcordata and A. dolichocarpa placed in the same group close to each other, and A. djavanshirii was clustered separately. However, in nuclear ribosomal ITS and chloroplast trnH$p s b A$ intergenic spacer analyses $A$. dolichocarpa and $A$. djavanshirii, did not reveal any diagnostic sites and had a similar pattern with $A$. subcordata.
In addition, $A$. orientalis and $A$. subcordata var. subcordata were clustered in the same group, in similar with the previous phylogenetic study (Hosseinzadeh-Colagar et al., 2016).

\section{Conclusion}

We investigated seed qualitative and quantitative morphological characteristics of 10 Alnus taxa in Iran to compare their morphological characteristics and study of their taxonomic importance in identification of taxa at species as well as infraspecific levels. Our finding revealed that most of seed morphological characteristics, especially qualitative ones, could be considered as a valuable taxonomic tool at the species level. By contrast, their diagnostic value at infraspecific ranks, especially subspecies, is questionable. But two varieties of A. subcordata can be distinguished by those traits. However, some characteristics including seed color had not taxonomical importance. According to seed features, the studied taxa were divided into three groups and each of taxa was characterized by special seed feature(s). In some cases, taxa clustering were similar with the previous morphological and phylogenetic studies.

\section{REFERENCES}

Ashburner K. 1986. Alnus: a survey. Plantsman 8: 170-188.

Boissier E. 1867. Flora Orientalis. H. Georg in Basileae. Pp. 1179-1180.

Brochmann C. 1992. Pollen and seed morphology of Nordic Draba (Brassicaceae): phylogenetic and ecological implications. Nord. J. Bot. 12: 657-673.

Browicz K. 1972: Betulaceae. In: Flora Iranica. № 96. Ed. K. H. Rechinger. Graz. Pp. 5-8.

Chen Z. D. 1994. Phylogeny and phytogeography of the Betulaceae. Acta Phytotax. Sin. 32: 1-32.

Chen Z., Li J. 2004. Phylogenetics and biogeography of Alnus (Betulaceae) inferred from sequences of nuclear ribosomal DNA its region. Int. J. Plant Sci. 165: 132-135. DOI: 10.1086/382795

Gholamiterojeni T., Sharifnia F., Nejadsattari T., Assadi M., Hamdi S. M. M. 2019. Revision of Alnus (Betulaceae) in Iran using molecular ITS markers and morphological characteristics. Biologija 65(2): 90-104.

Govaerts R., Frodin D. G. 1998. World Checklist and Bibliography of Fagales. Kew: Royal botanical garden. Pp. $17-23$.

Hosseinzadeh-Colagar A., Yousefzadeh H., Shayanmehr F., Gholamali Jalali S., Zare H., Tippery N. P. 2016. Molecular taxonomy of Hyrcanian Alnus using nuclear ribosomal ITS and chloroplast trnH-psbA DNA barcode markers. System. Biodivers. 14(1): 88-101. DOI: 10.1080/14772000.2015.1102172

Kaya A., Unal M., Ozgokce F., Dogan B., Martin E. 2011. Fruit and seed morphology of six species previously placed in Malcolmia (Brassicaceae) in Turkey and their taxonomic value. Turk. J. Botany 35: 653-662.

Koul K. K., Ranjna N., Raina S. N. 2000. Seed coat microsculpturing in Brassica and allied genera (subtribes Brassicinae, Raphaninae, Moricandiinae). Ann. Bot. 86: 385-397.

Kuzeneva O. I. 1936. Betulaceae. In: Flora SSSR [Flora of the USSR]. Vol. 5. Ed. V. L. Komarov. Moscow; Leningrad: Publishers of Academy of Sciences of USSR. Pp. 269-319. [In Russian] (Кузенева О. И. Betulaceae // Флора СССР. Т. 5. Под ред. В. Л. Комарова. М.; Л.: АН СССР, 1936. С. 269-319).

Miki A. 1997. Late cretaceous pollen and spore floras of northern Japan: composition and interpretation. J. Fac. Sci. Hokkaido Univ. Ser. Iv. Geol. Mineral 17: 399-436.

Mobayen S. 1985. Flora of Iran: Vascular Plants. University of Tehran Press. Pp. 73-87. 
Murai S. 1964. Phytotaxonomical and geobotanical studies on gen. Alnus in Japan. III. Taxonomy of whole world species and distribution of each sect. Bull. Gov. For Exp. Stn Jpn 171: 1-107.

Navarro E., Bousquet J., Moiroud A., Munive A., Piou D., Normand P. 2003. Molecular phylogeny of Alnus (Betulaceae) inferred from nuclear ribosomal DNA. Plant Soil 254: 207-217. DOI: 10.1023/A:1024978409187

Podani J. 2000. Introduction to the Exploration of Multivariate Biological Data. Leiden. 407 pp.

Shayanmehr F., Jalali S. G., Hosseinzadeh-Colagar A., Zare H., Kartoolinejad D., Yousefzade H. 2018. Leaf cuticle and wax ultrastructure of genus Alnus Mill., in Hyrcanian forests of Iran. Int. J. Environ. Stud. 75(6): 877-890. DOI: 10.1080/00207233.2018.1464278

Shayanmehr F., Jalali S.G., Hosseinzadeh-Colagar A., Zare H., Yousefzadeh H. 2014. Morphological variations of genus Alnus in Iran: assessment of five new taxa. Taxonomy and Biosystematics Journal 6, 18: 45-64.

Sukhorukov A. P., Nilova M. V., Krinitsina A. A., Zaika M. A., Erst A. S., Shepherd K. A. 2018. Molecular phylogenetic data and seed coat anatomy resolve the generic position of some critical Chenopodioideae (Chenopodiaceae-Amaranthaceae) with reduced perianth segments. PhytoKeys 109: 103-128. DOI: 10.3897/phytokeys.109.28956

Talebi S. M., Sheidai M., Atri M., Sharifnia F., Noormohammadi Z. 2012. Seed micromorphology study of the genus Linum L. (Linaceae) in Iran. Ann. Biol. Res. 3: 668-672.

Talebi S. M., Tabaripour R., Eskandari M. 2019. Analysis of nutlet morphological characteristics of some Iranian Ajuga L. taxa. Biodiversitas 20: 2833-2840. DOI: 10.13057/biodiv/d201008

Yaltrik Y. 1982. Betulaceae. In: Flora of Turkey. Vol. 7. Ed. P. H. Davis. Edinburgh. Pp. 688-694.

Zare H., Amini T. 2012. A review of the genus Alnus Gaertn. in Iran, new records and new species. Iran. J. Bot. 18(1): 10-21. 